\title{
Influence of Salt on the Self-Organization in Solutions of Star-Shaped Poly-2-alkyl-2-oxazoline and Poly-2-alkyl-2-oxazine on Heating
}

\author{
Tatyana Kirila *(D), Anna Smirnova, Alla Razina, Andrey Tenkovtsev and Alexander Filippov
}

check for

updates

Citation: Kirila, T.; Smirnova, A.; Razina, A.; Tenkovtsev, A.; Filippov,

A. Influence of Salt on the

Self-Organization in Solutions of

Star-Shaped Poly-2-alkyl-2-oxazoline and Poly-2-alkyl-2-oxazine on

Heating. Polymers 2021, 13, 1152.

https://doi.org/10.3390/

polym 13071152

Academic Editor: Sasaki Takashi

Received: 27 February 2021

Accepted: 1 April 2021

Published: 4 April 2021

Publisher's Note: MDPI stays neutral with regard to jurisdictional claims in published maps and institutional affiliations.

Copyright: (c) 2021 by the authors. Licensee MDPI, Basel, Switzerland. This article is an open access article distributed under the terms and conditions of the Creative Commons Attribution (CC BY) license (https:// creativecommons.org/licenses/by/ $4.0 /)$.
Institute of Macromolecular Compounds of the Russian Academy of Sciences, Bolshoy Pr. 31, 199004 Saint Petersburg, Russia; av.smirnova536@gmail.com (A.S.); allarazina@yahoo.com (A.R.); avt@hq.macro.ru (A.T.); afil@imc.macro.ru (A.F.)

* Correspondence: tatyana_pyx@mail.ru; Tel.: +7-812-328-4102

Abstract: The water-salt solutions of star-shaped six-arm poly-2-alkyl-2-oxazines and poly-2-alkyl-2oxazolines were studied by light scattering and turbidimetry. The core was hexaaza[26 $]$ orthoparacyclophane and the arms were poly-2-ethyl-2-oxazine, poly-2-isopropyl-2-oxazine, poly-2-ethyl-2-oxazoline, and poly-2-isopropyl-2-oxazoline. $\mathrm{NaCl}$ and $\mathrm{N}$-methylpyridinium $p$-toluenesulfonate were used as salts. Their concentration varied from 0-0.154 M. On heating, a phase transition was observed in all studied solutions. It was found that the effect of salt on the thermosensitivity of the investigated stars depends on the structure of the salt and polymer and on the salt content in the solution. The phase separation temperature decreased with an increase in the hydrophobicity of the polymers, which is caused by both a growth of the side radical size and an elongation of the monomer unit. For $\mathrm{NaCl}$ solutions, the phase separation temperature monotonically decreased with growth of salt concentration. In solutions with methylpyridinium p-toluenesulfonate, the dependence of the phase separation temperature on the salt concentration was non-monotonic with minimum at salt concentration corresponding to one salt molecule per one arm of a polymer star. Poly-2-alkyl-2oxazine and poly-2-alkyl-2-oxazoline stars with a hexaaza[2 6 ]orthoparacyclophane core are more sensitive to the presence of salt in solution than the similar stars with a calix[n]arene branching center.

Keywords: star-shaped polymer; poly-2-alkyl-2-oxazines and poly-2-alkyl-2-oxazolines; saline solution; thermoresponsive polymers

\section{Introduction}

The key property of "smart polymers", which determines a wide range of their practical use, is a nonlinear response to an external signal. In the case of thermoresponsive polymers, the phase transition in aqueous solutions is induced by temperature change. Accordingly, the temperature variation is a simple way to control the behavior of their solutions [1-6]. Thermoresponsive polymers are highly appealing for medical applications and biotechnology if the phase separation temperature is close to body temperature [7-14]. Polymers used in biomedical applications must be non-toxic, biocompatible, stable in biological media, biodegradable, and/or completely excreted from the body. These requirements are satisfied by poly-2-alkyl-2-oxazolines (PAlOx) and poly-2-alkyl-2-oxazines (PAlOz), many of which exhibit a thermosensitivity with a lower critical solution temperature.

$\mathrm{PAlOx}$ and $\mathrm{PAlOz}$, sometimes called pseudo-polypeptoids, are obtained by (living) cationic ring-opening polymerization of corresponding monomers [15-21]. In recent years, a large number of thermoresponsive PAlOx of various chemical structures have been obtained, including statistical, block and gradient copolymers, and graft and star-shaped polymers [22-25]. The processes of polymerization, in particular, the kinetics of polymerization upon initiation by alkyl halides, tosylates, nosylates, and triflates have been studied in detail [26,27]. Regularities of behavior in aqueous solutions with temperature variation 
were established for PAlOx, and features that distinguish them from other thermosensitive polymers were revealed [28-34]. It has been found that the introduction of fragments ready for effective binding of inorganic ions and organic compounds, for example, azamacrocycles, is an effective strategy for the construction of supramolecular structures, thereby allowing to simulate the processes occurring in living nature [35-37].

The polymerization process of $\mathrm{PAlOz}$ is characterized by low polymerization rate constants and a high chain transfer rate, which makes it difficult to obtain high molar mass samples $[19,21]$. Until recently, this was one of the reasons for the small number of works devoted to the study of this promising class of thermosensitive polymers. Nonetheless, at the present time, the effect of the structure of the monomer unit and end groups on the properties of linear PAlOz [14,19,21,38-40], including their thermosensitivity [14,41,42], has been established. It was shown that the hydration of $\mathrm{PAlOz}$ is determined by the structure of the side radical. An additional methylene group in the backbone makes PAlOz more hydrophobic than PAlOx with the same side alkyl radical, which leads to a decrease in the cloud point of aqueous solutions [42]. The most significant is that an increase in the binding of water-insoluble drugs was found for PAlOz in comparison with PAlOx [14,41,43]. The latter indicates good prospects for the use of $\mathrm{PAlOz}$ and their copolymers in medicine.

It is well known that star-shaped polymers have very good prospects for use in medical applications [44,45], for example, for drug delivery [46], for selective adhesion of cancer cells [47], in tissue engineering, and cell uptake [48,49]. This circumstance has intensified research in the field of synthesis and determination of the properties of stimulisensitive polymers with complex architecture [50,51], including star-shaped PAlOx. The studies performed have revealed a number of interesting regularities in the behavior of polymers with complex architecture in aqueous solutions. For example, for a number of classes of star-shaped polymers, the influence of the core structure, the length and number of arms on the self-organization and aggregation has been established [12,52-57]. Recently, for the first time, star-shaped PAlOz were synthesized and studied [58-60].

The use of thermoresponsive PAlOx and $\mathrm{PAlOz}$ as materials for drug delivery is due to their ability to form intra- and intermolecular hydrogen bonds, resulting in the compaction and aggregation of individual polymer chains [61-65]. The physiological media is a complex system containing a variety of ions that affect the balance of hydrogen bonds. Accordingly, the behavior of thermoresponsive polymers in aqueous solutions and physiological media can differ significantly. For example, even a small $\mathrm{NaCl}$ content in the solution significantly changed the phase separation temperatures [66-68]. Moreover, the presence of salt affects the thermosensitivity of the linear and star-shaped polymers in different ways [60-69].

The goal of this work is to analyze the effect of the chemical structure and concentration of low molecular weight salts on the behavior of the star-shaped PAlOx and PAlOz in watersalt solutions. Four star-shaped polymers with a hexaase[2 $2_{6}$ ]orthoparacyclophane $(\mathrm{CPh} 6)$ core were investigated, namely, poly-2-ethyl-2-oxazine (CPh6-PEtOz), poly-2-isopropyl-2oxazine (CPh6-PiPrOz), poly-2-ethyl-2-oxazoline (CPh6-PEtOx), and poly-2-isopropyl-2oxazoline (CPh6-PiPrOx) (Figure 1). $\mathrm{NaCl}$ and $\mathrm{N}$-methylpyridinium $p$-toluenesulfonate (N-PTS, Figure 2) were used as salts. N-PTS can be considered as a model for cetylpyridinium chloride known for its antimicrobial and antifungal effects. N-PTS influences the self-organization in solution of thermoresponsive polymers [70], because both $N$-methyl pyridinium cation and tosylate anion affect the hydrogen bond network of water [71-74]. 


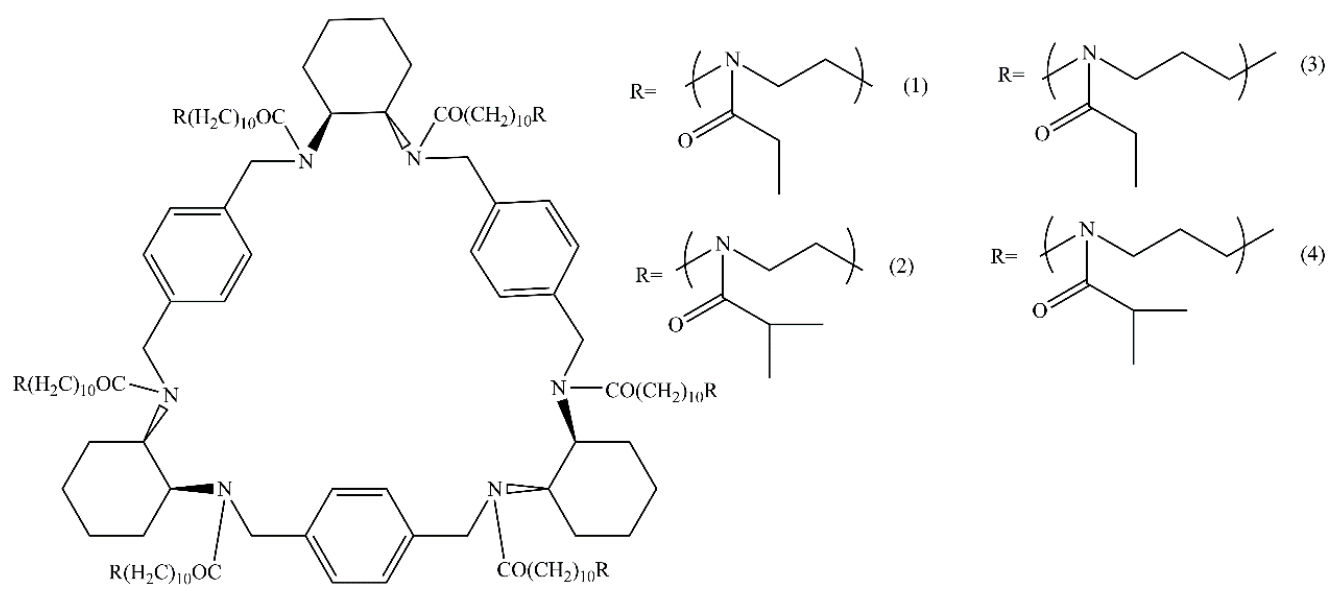

Figure 1. Structure of star-shaped poly-2-ethyl-2-oxazoline (1), poly-2-isopropyl-2-oxazoline (2), poly-2-ethyl-2-oxazine (3), and poly-2-isopropyl-2-oxazine (4).

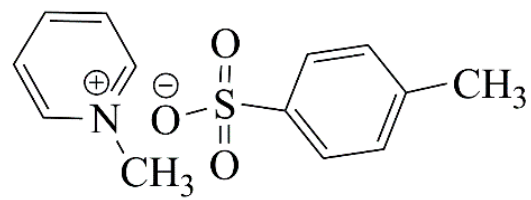

Figure 2. Structure of $N$-methylpyridinium $p$-toluenesulfonate.

\section{Materials and Methods}

\subsection{Polymer Star Synthesis}

The synthesis and characterization of star-shaped six-arm thermoresponsive poly-2alkyl-2-oxazolines (CPh6-PAlOx) and poly-2-alkyl-2-oxazines (CPh6-PAlOz) with a hexaase[ $2_{6}$ ]orthoparacyclophane core has been described in detail previously [59]. CPh6$\mathrm{PAlOx}$ and $\mathrm{CPh} 6-\mathrm{PAlOz}$ were synthesized by cationic ring-opening polymerization of the corresponding 2-alkyl-2-oxazoline or 2-alkyl-2-oxazine derivative. The molar masses $(\mathrm{MM})$ and hydrodynamic characteristics of the samples were determined in chloroform dilute solutions using the sedimentation-diffusion analysis and viscosity. MM were moderate: $23,000 \mathrm{~g} \cdot \mathrm{mol}^{-1}$ for $\mathrm{CPh} 6-\mathrm{PEtOz}, 20,000 \mathrm{~g} \cdot \mathrm{mol}^{-1}$ for CPh6-PiPrOz, $15,000 \mathrm{~g} \cdot \mathrm{mol}^{-1}$ for CPh6-PEtOx, and 14,000 g. $\mathrm{mol}^{-1}$ for CPh6-PiPrOx [59]. Accordingly, the molar masses of $\mathrm{CPh} 6-\mathrm{PAlOz}$ are slightly higher than $\mathrm{MM}$ of CPh6-PAlOx.

The solvents and reagents (all Sigma Aldrich, St. Louis, MO, USA) were purified and dried according to the standard techniques. Trianglamine (1) [11] as well as 2-alkyl-2oxazolines and 2-alkyl-2-oxazines [41] were synthesized by the generally applied methods.

\subsection{Solution Investigation}

The behavior of $\mathrm{CPh} 6-\mathrm{PAlOz}$ and $\mathrm{CPh} 6-\mathrm{PAlOx}$ in water-salt solutions was studied at polymer concentration $c=0.0050 \mathrm{~g} \cdot \mathrm{cm}^{-3}$. For $\mathrm{NaCl}$ solutions, the salt concentrations $c_{\text {salt }}$ were selected as one $\mathrm{NaCl}$ formula unit per one macromolecule, per one arm of the polymer star and per one monomer unit. Besides, physiological saline $(0.154 \mathrm{M})$ and pure aqueous solutions were investigated. In the case $\mathrm{N}$-PTS solutions, the $c_{\text {salt }}$ values were chosen in a similar way: one N-PTS molecule per one macromolecule, per one arm of the polymer star, and per one monomer unit. To expand the range of $\mathrm{N}$-PTS content, solutions at $c_{\text {salt }} \approx 0.10$ and $0.15 \mathrm{M}$ were prepared and studied. Thus, for both water-salt solvents, the salt concentration varied from $0-1.54 \mathrm{M}$.

The solutions and solvent were filtered into cells previously dedusted by benzene. Chromafil Xtra filters (Macherey-Nagel, Dueren, Germany) with a PTFE membrane with the pore size of $0.45 \mu \mathrm{m}$ were used.

The self-organization in water-salt solutions of CPh6-PAlOz and CPh6-PAlOx was studied by light scattering and turbidimetry on a PhotoCor Complex setup (Photocor In- 
struments Inc., Moscow, Russia) with a sensor for measuring optical transmission. The light source was the Photocor-DL diode laser with wavelength $\lambda=659.1 \mathrm{~nm}$ and controllable power up to $30 \mathrm{~mW}$. The correlation function of the scattered light intensity was obtained using the Photocor-PC2 correlator with 288 channels and processed using the DynalS software. The solution temperature $T$ was changed discretely within the interval from $9-80^{\circ} \mathrm{C}$, with the steps ranging from 0.5 (near phase separation) to $6{ }^{\circ} \mathrm{C}$ (low temperatures). The temperature was regulated with the precision of $0.1^{\circ} \mathrm{C}$. The heating rate was $1.5^{\circ} \mathrm{C} \cdot \mathrm{min}^{-1}$.

The measurement procedure has been described in detail previously [55]. After the given temperature was achieved, all solution characteristics (light scattering intensity $I$, optical transmittance $I^{*}$, and hydrodynamic radii $R_{\mathrm{h}}$ of the scattering particles) began to change with time $t$. If intensity $I$ changed at a high rate, the dependence of $I$ (at the scattering angle $90^{\circ}$ ) and $I^{*}$ on time was measured only. The analysis of these dependencies makes it possible to determine the time of establishment of the "equilibrium" state of the system, in which $I, I^{*}$ and $R_{\mathrm{h}}$ cease to change in time at given temperature. The hydrodynamic radii $\mathrm{Rh}$ of dissolved particles were determined when the intensity changed very weakly or independent of $t$. It should be noted that the values of $R_{\mathrm{h}}$ can be obtained correctly if the light scattering intensity differs no more than $1 \%$ from its average value. Figure 3 as an example demonstrates the dependences of relative intensity $I / I_{\max }$ of scattered light on the hydrodynamic radius $R_{\mathrm{h}}$ of scattering species for CPh6-PEtOz water-salt solutions ( $I_{\max }$ is the maximum value of light scattering intensity I for a given solution). It is necessary to emphasize that the experiment time was equal to $1800 \mathrm{~s}$ at least at each temperature even if the measured characteristics did not depend on time. In "equilibrium" conditions, the angle dependences of $I$ and $R_{\mathrm{h}}$ were also analyzed within intervals from $45-135^{\circ}$ in order to justify the diffusion process (Figure 4 ).
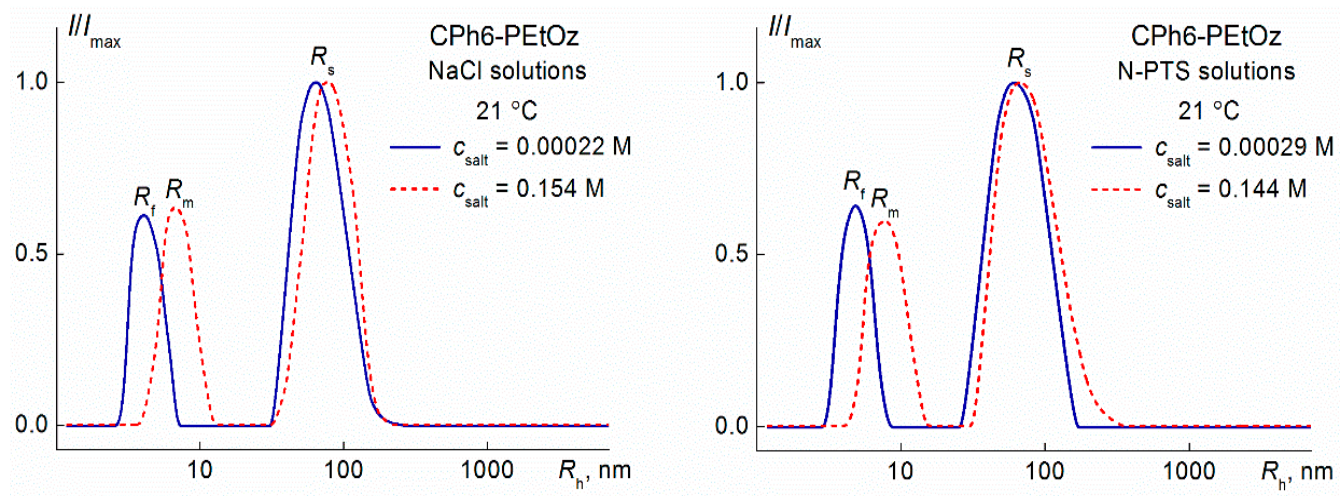

Figure 3. Dependences of relative light scattering intensity $I / I_{\max }$ on the hydrodynamic radius $R_{\mathrm{h}}$ of scattering species for CPh6-PEtOz solutions at $21{ }^{\circ} \mathrm{C}$. (Variables $R_{\mathrm{f}}, R_{\mathrm{m}}$ and $R_{\mathrm{s}}$ will be discussed in Section 3.1).
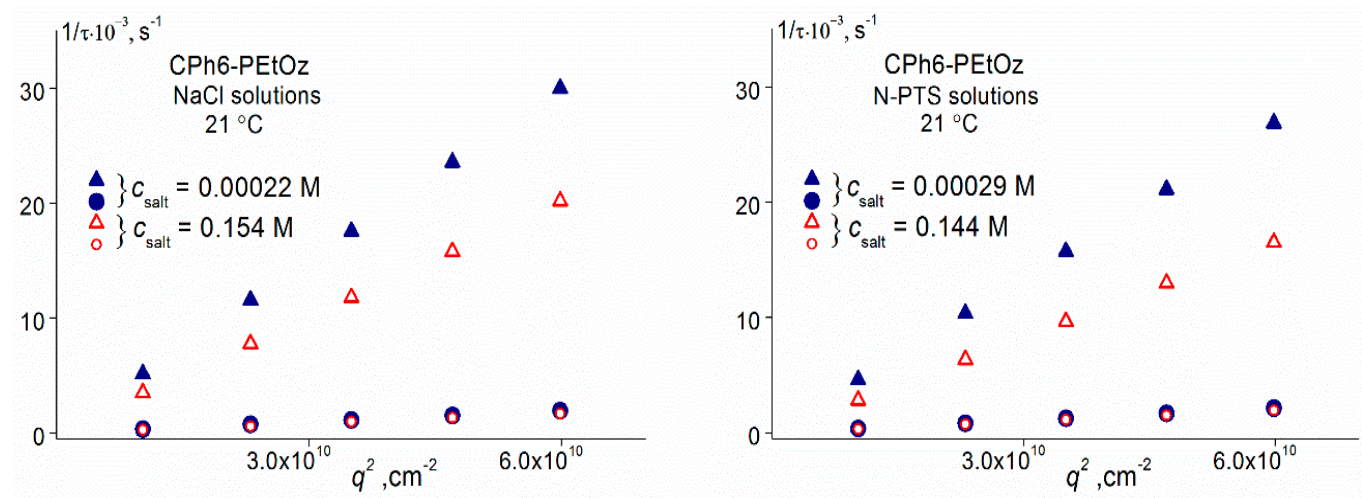

Figure 4. Relaxation time $1 / \tau$ on squared wave vector $\mathrm{q}^{2}$ for $\mathrm{CPh} 6-\mathrm{PEtOz}$ solutions at $21^{\circ} \mathrm{C}$. 


\section{Results and Discussion}

3.1. Behavior of Star-Shaped Six-Arm Pseudo-Polypeptoids in Water-Salt Solutions at Low Temperatures

The behavior of water-salt solutions of the studied polymer stars depends on the chemical structure of both the arms and the salts. In CPh6-PAlOx solutions, the addition of $\mathrm{NaCl}$ and N-PTS does not change the set of scattering objects. Figure 5 shows the dependences of the hydrodynamic radii $R_{\mathrm{h}}$ of the particles present in the solutions on the salt concentration $c_{\text {salt }}$ for CPh6-PAlOx. For all values of $c_{\text {salt }}$, two types of particles with radii $R_{\mathrm{m}}$ (small particles) and $R_{S}$ (large particles) were found in CPh6-PAlOx solutions. For both salts, $R_{\mathrm{m}}$ did not depend on the salt content. In the case of CPh6-PEtOx, the average values $\left\langle R_{\mathrm{m}}>=(7.4 \pm 0.4) \mathrm{nm}\right.$ for $\mathrm{NaCl}$ solutions and $(7.0 \pm 0.4) \mathrm{nm}$ for $N$-PTS solutions are approximately $2.5 \times$ larger than the hydrodynamic radius $R_{\mathrm{h}-\mathrm{D}}=3.0 \mathrm{~nm}$ of CPh6-PEtOx molecules [59]. For the more hydrophobic CPh6-PiPrOx, the hydrodynamic radius $<R_{\mathrm{m}}>$ is about $18 \mathrm{~nm}$ in both solvents, while the macromolecule radius $R_{\mathrm{h}-\mathrm{D}}$ was $2.6 \mathrm{~nm}$ [59]. Consequently, just as in pure water in water-salt solutions of CPh6-PAlOx, the species with radius $R_{\mathrm{m}}$ are small aggregates, the reason for the formation of which is the interaction of hydrophobic $\mathrm{CPh} 6$ cores. These so-called micelle-like structures [75-78] were often observed in solutions of star-shaped PAlOx $[79,80]$. Taking into account that the form of star-shaped macromolecules with short arms and micelle-like structures [81] is close to spherical, the aggregation degree $m_{\mathrm{agg}}$ can be estimated by comparing the volumes of macromolecules and aggregates using the formula:

$$
m_{\mathrm{agg}} \approx\left(R_{\mathrm{m}} / R_{\mathrm{h}-\mathrm{D}}\right)^{3}
$$
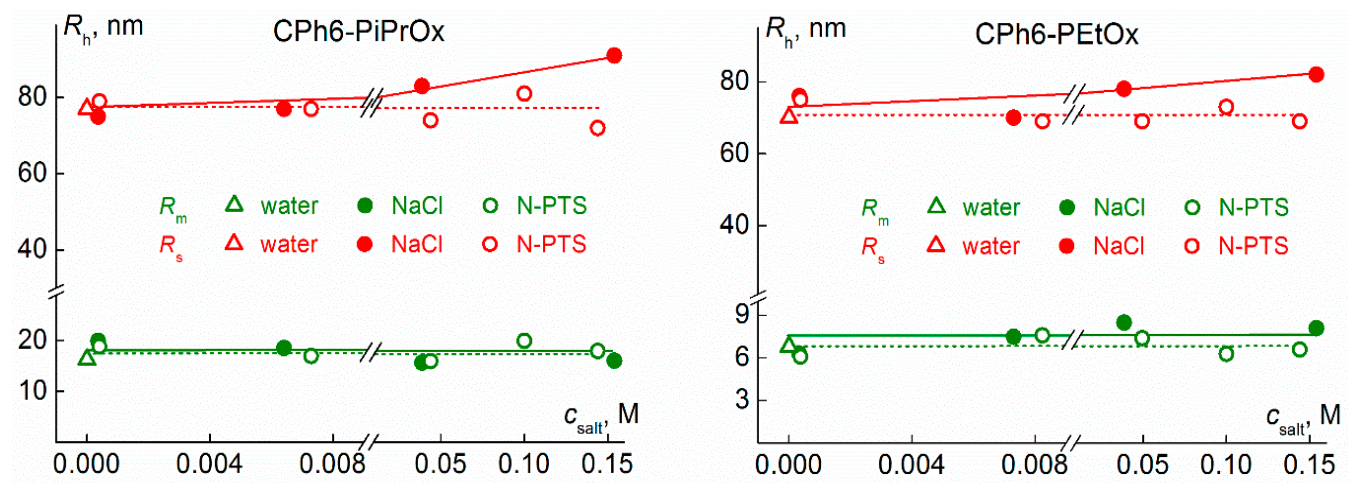

Figure 5. Dependences of hydrodynamic radii $R_{\mathrm{m}}$ and $R_{\mathrm{s}}$ of scattering objects on salt concentration $c_{\text {salt }}$ for solutions of CPh6-PiPrOx at $11^{\circ} \mathrm{C}$ and CPh6-PEtOx at $21^{\circ} \mathrm{C}$. In the Figures 5, 6, 11 and 12 for all polymers and for both salts, the first point on the dependences refers to an aqueous solution, and the second, third and fourth points correspond to the following salt contents: one salt molecule per one macromolecule, per one arm of the polymer star, and per one monomer unit, respectively.
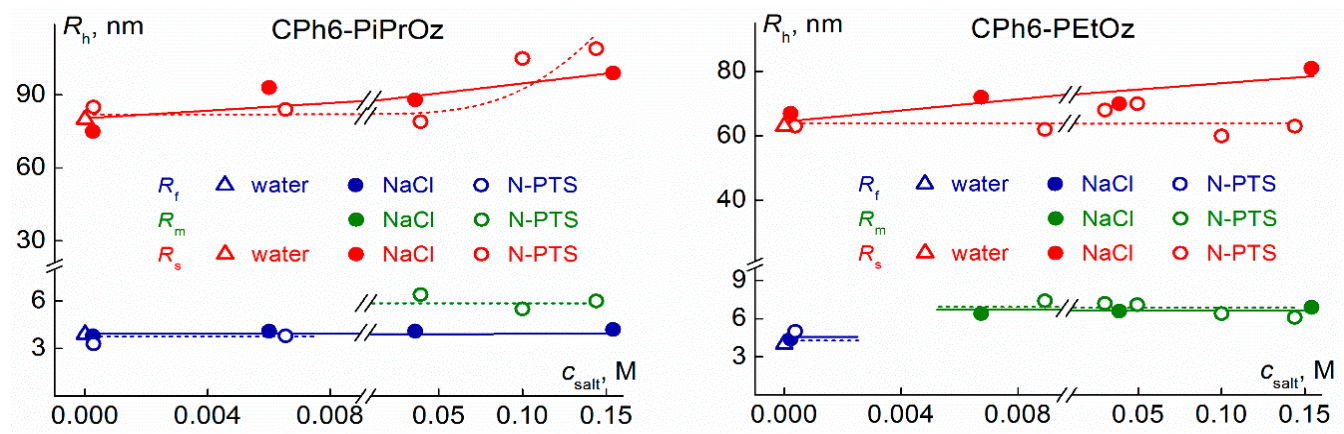

Figure 6. The dependences of the hydrodynamic radii $R_{\mathrm{f}}, R_{\mathrm{m}}$ and $R_{\mathrm{S}}$ on the salt concentration $c_{\mathrm{salt}}$ for solutions of $\mathrm{CPh} 6-\mathrm{PiPrOz}$ at $11^{\circ} \mathrm{C}$ and $\mathrm{CPh} 6-\mathrm{PEtOz}$ at $21^{\circ} \mathrm{C}$. 
Using Equation (1), it is also assumed that the densities of macromolecules and micellelike structures are the same. For CPh6-PEtOx, the aggregation degree is low ( $\left.m_{\mathrm{agg}} \approx 15\right)$, whereas for the more hydrophobic CPh6-PiPrOx, the $m_{\text {agg }}$ value approaches 300 .

As for large scattering objects with a hydrodynamic radius $R_{\mathrm{S}}$, these are large loose aggregates. The addition of $\mathrm{NaCl}$ and $\mathrm{N}$-PTS to the solution has a different effect on the size of these aggregates. The value $R_{\mathrm{S}}$ is independent of the concentration of N-PTS and increases with growth of $\mathrm{NaCl}$ content in solution (Figure 5).

In the case of $\mathrm{CPh} 6-\mathrm{PAlOz}$, the addition of salts leads to a change in the set of scattering objects (Figure 6). At low temperatures, two types of species were also observed in aqueous solutions of these star-shaped polymers. However, unlike CPh6-PAlOx, the smaller particles were macromolecules. Indeed, the hydrodynamic radius $R_{\mathrm{f}}$ of these objects coincided within the experimental error with the radius $R_{\mathrm{h}-\mathrm{D}}$ of macromolecules [59]. In $\mathrm{NaCl}$ solutions of $\mathrm{CPh} 6-\mathrm{PiPrOz}$, macromolecules and large aggregates were present in the studied range of the salt concentration $c_{\text {salt }}$. The $R_{\mathrm{f}}$ value did not depend on the $\mathrm{NaCl}$ content, while the $R_{\mathrm{s}}$ radius increased with the growth of $\mathrm{NaCl}$ concentration. A completely different behavior was observed for $\mathrm{CPh} 6-\mathrm{PiPrOz}$ solutions in the presence of N-PTS. Macromolecules were detected only at low N-PTS content. At $c_{\text {salt }}=0.039 \mathrm{M}$, particles with a hydrodynamic radius $R_{\mathrm{m}}$ appeared in solutions, and at $c_{\text {salt }}>0.01 \mathrm{M}$, species with radius $R_{\mathrm{f}}$ were not observed by dynamic light scattering (Figure 6). The $R_{\mathrm{m}}$ values do not depend on the salt concentration. The average value $\left\langle R_{\mathrm{m}}\right\rangle=(6.1 \pm 0.4) \mathrm{nm}$, and therefore, taking into account that $R_{\mathrm{h}-\mathrm{D}}=3.0 \mathrm{~nm}$ [59], the aggregation degree is $m_{\mathrm{agg}} \approx 8$. This is half the $m_{\mathrm{agg}}$ value for $\mathrm{N}$-PTS solutions of CPh6-PEtOx. At a low N-PTS content, the hydrodynamic size of large aggregates is close to $70 \mathrm{~nm}$, and at $c_{\text {salt }}>0.05 \mathrm{M}$, the $R_{\mathrm{s}}$ value increased, reaching $110 \mathrm{~nm}$. Thus, at $c_{\text {salt }}>0.07 \mathrm{M}$ in N-PTS solutions of CPh6-PiPrOz, micelle-like structures and large aggregates existed, which coincides with the set of scattering objects in water-salt solutions of CPh6-PAlOx.

In both water-salt solutions, the behavior of CPh6-PEtOz was similar to that observed for $N$-PTS solutions of CPh6-PiPrOz, namely, at a certain concentration $c_{\text {salt }}$, micelle-like aggregates were formed in the solutions. Their hydrodynamic radius $R_{\mathrm{m}}$ did not change with $c_{\text {salt }}$. The average values $<R_{\mathrm{m}}>$ were $(6.6 \pm 0.4) \mathrm{nm}$ and $(6.9 \pm 0.4) \mathrm{nm}$ for solutions with $\mathrm{NaCl}$ and $\mathrm{N}$-PTS, respectively. Small radii of micelle-like aggregates indicate that they contain a small number of macromolecules, and the estimation of the aggregation degree according to Equation (1) leads to a value of $m_{\mathrm{agg}} \approx 7$. Thus, the size of micelle-like aggregates formed in water-salt solutions of $\mathrm{CPh} 6-\mathrm{PAlOz}$ is smaller than the corresponding characteristics for $\mathrm{CPh} 6-\mathrm{PAlOx}$. This can be explained by the fact that the arms of the $\mathrm{CPh} 6$ $\mathrm{PAlOz}$ molecules are longer [59] and better screen the nucleus. As regards the size of large aggregates, for CPh6-PEtOz, the $R_{\mathrm{S}}$ value does not depend on the N-PTS content and increases with the $\mathrm{NaCl}$ concentration (Figure 6).

Concluding the discussion of the behavior of water-salt solutions of CPh6-PAlOz at low temperatures, the following fact should be noted. The appearance of micelle-like aggregates in all cases occurs at a concentration $c_{\text {salt }}$, which approximately corresponds to one salt molecule per one arm of a polymer star.

\subsection{Temperature Dependences of Characteristics of Star-Shaped Pseudo-Dendrimers Water-Salt Solutions}

All the results discussed below were obtained for a state of the investigated solutions when their characteristics (light scattering intensity $I$, optical transmission $I^{*}$, hydrodynamic radii of scattering species $R_{\mathrm{h}}$, etc.) do not change with time. For the systems under study, the establishment time $t_{\text {eq }}$ of such "equilibrium" state after a discrete change in temperature is rather long. This is illustrated in Figure 7, which shows typical dependences of $I$ and $I^{*}$ on time $t$. The moment when the solution temperature reached a given value was taken as $t=0$. For each solution, the $t_{\mathrm{eq}}$ value depended on temperature. As well as for other thermoresponsive polymers [82], at each $c_{\text {salt }}$ value, the establishment time $t_{\text {eq }}$ had a maximum value $t_{\mathrm{eq}}{ }^{(\mathrm{max})}$ near the onset of phase separation. For the studied polymer 
stars, no systematic change in $t_{\mathrm{eq}}{ }^{(\max )}$ was found with a change in the salt content. Average values $<t_{\mathrm{eq}}{ }^{(\mathrm{max})}>$ of maximum value of establishment time for each polymer are given in Table 1. They are noticeably less than $<t_{\mathrm{eq}}{ }^{(\mathrm{max})}>$ for star-shaped eight- and four-arm PAlOx with a calix[n]arene core [82]. This is probably the effect of the structure of the branching center on the rate of self-organization of star-shaped polymers. The data in Table 1 show that the maximum establishment time for stars with side isopropyl groups is greater than $<t_{\mathrm{eq}}{ }^{(\max )}>$ for polymers with ethyl groups. Thus, an increase in the volume of the side radical slows down the aggregation processes in water-salt solutions of the star-shaped CPh6-PAlOz and CPh6-PAlOx. Note that earlier a decrease in the $\left\langle t_{\mathrm{eq}}{ }^{(\max )}>\right.$ value with the passage from PiPrOx to PEtOx was found for PAlOx stars with a calix[n]arene core [81]. On the other hand, the influence of the salt structure on the times of establishing the equilibrium state has not been revealed. Indeed, for all studied polymers, the values of $<t_{\mathrm{eq}}{ }^{(\mathrm{max})}>$ in solutions with $\mathrm{NaCl}$ and N-PTS coincide within the experimental error.
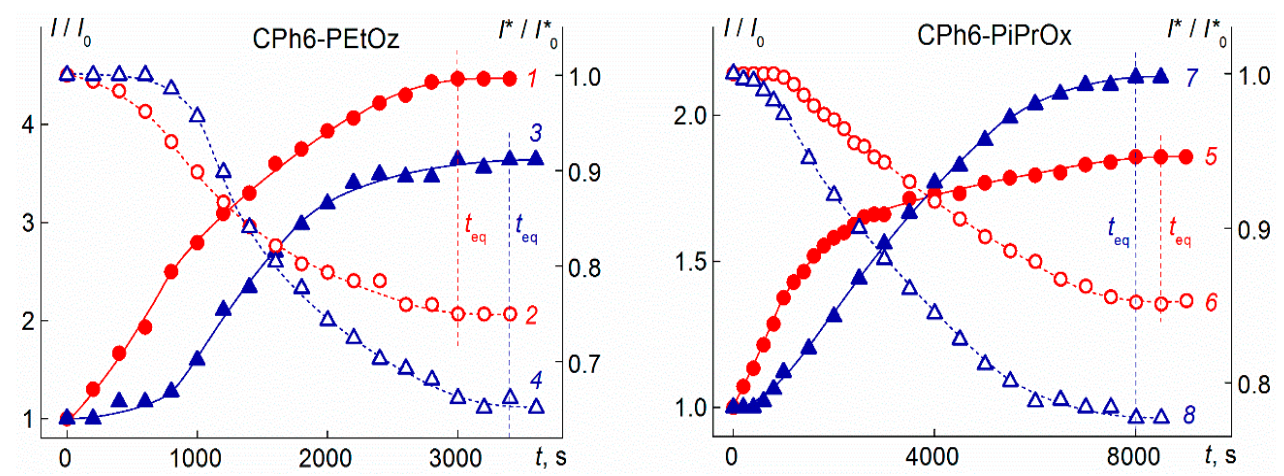

Figure 7. Dependences of relative light scattering intensity $I / I_{0}(1,3,5$, and 7 ; closed symbols) and optical transmission $I^{*} / I_{0}^{*}(2,4,6$, and 8; open symbols) on time $\mathrm{t}$ for water-salt solutions of investigate polymer stars. Left panel: $\mathrm{CPh} 6-\mathrm{PEtOz}$ solutions at $\mathrm{NaCl}$ concentration $c_{\text {salt }}=0.00674 \mathrm{M}$ and $T=62{ }^{\circ} \mathrm{C}(1$ and 2$)$ and at $N$-PTS concentration $c_{\text {salt }}=0.00892 \mathrm{M}$ and $T=31^{\circ} \mathrm{C}(3$ and 4$)$. Right panel: CPh6-PiPrOx solutions at $\mathrm{NaCl}$ concentration $c_{\text {salt }}=0.00641 \mathrm{M}$ and $\mathrm{T}=38^{\circ} \mathrm{C}(5$ and 6$)$ and at N-PTS concentration $c_{\text {salt }}=0.00803 \mathrm{M}$ and $T=27^{\circ} \mathrm{C}(7$ and 8$)$. Vertical lines mark the $t_{\text {eq }}$ value. $I_{0}$ and $I^{*}$ are values of light scattering intensity and optical transmission at $t=0$, respectively. In this Figure 7 and in Figures 8 and 9, the salt concentrations correspond to one salt molecule per one arm of the polymer star.
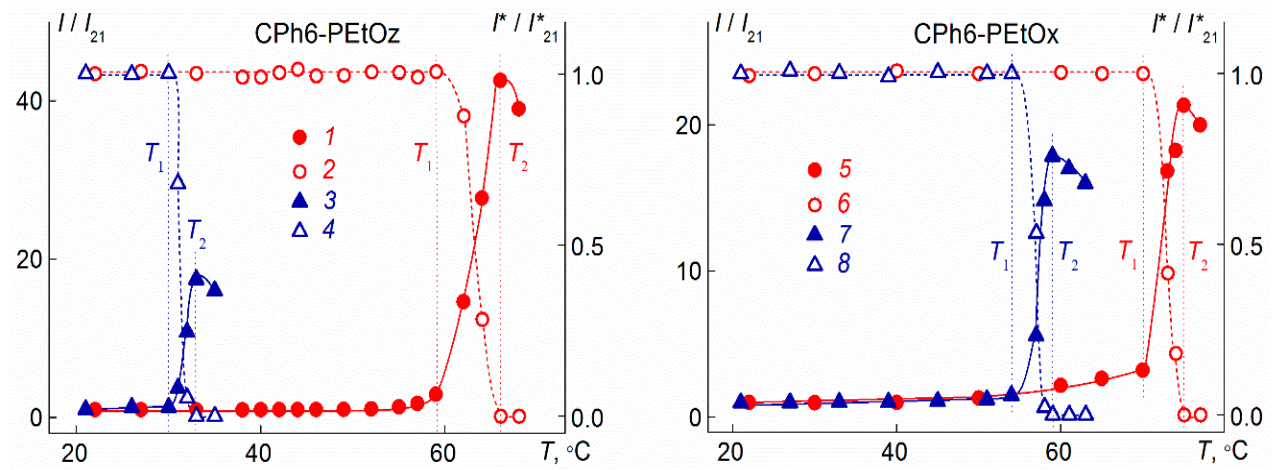

Figure 8. Dependences of relative light scattering intensity $I / I_{21}(1,3,5$, and 7; closed symbols) and optical transmission $I^{*} / I^{*}{ }_{21}(2,4,6$, and 8 ; open symbols) on temperature $T$ for water-salt solutions of investigated polymer stars. Left panel: $\mathrm{CPh} 6-\mathrm{PEtOz}$ solutions at $\mathrm{NaCl}$ concentration $c_{\text {salt }}=0.00674 \mathrm{M}$ ( 1 and 2 ) and at $N$-PTS concentration $c_{\text {salt }}=0.00892 \mathrm{M}$ (3 and 4). Right panel: CPh6-PEtOx solutions at $\mathrm{NaCl}$ concentration $c_{\text {salt }}=0.00730 \mathrm{M}(5$ and 6$)$ and at $N$-PTS concentration $c_{\text {salt }}=0.00824 \mathrm{M}(7$ and 8$)$. The vertical lines indicate the temperatures of the onset $T_{1}$ and the end of the $T_{2}$ phase transition for a given solution. $I_{21}$ and $I_{21}^{*}$ are values of light scattering intensity and optical transmission at $21^{\circ} \mathrm{C}$, respectively. 

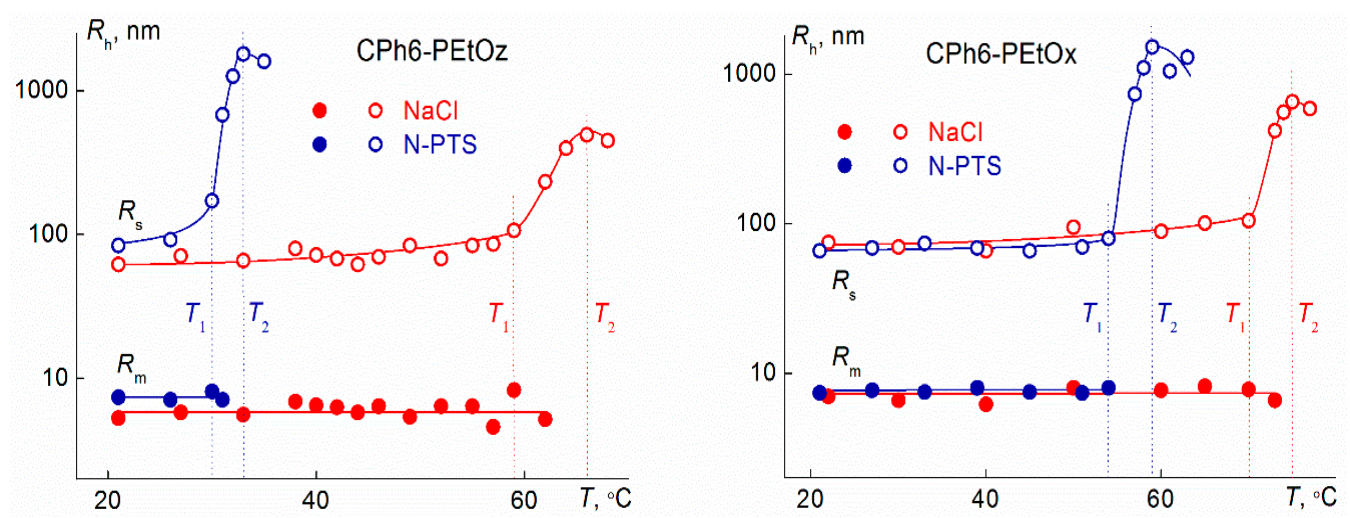

Figure 9. Dependences of hydrodynamic radii $R_{\mathrm{m}}$ (closed symbols) and $R_{\mathrm{S}}$ (closed symbols) on temperature $T$ for $\mathrm{CPh} 6-\mathrm{PEtOz}$ solutions at $\mathrm{NaCl}$ concentration $c_{\text {salt }}=0.00674 \mathrm{M}$ and at $N$-PTS concentration $c_{\text {salt }}=0.00892 \mathrm{M}$ and for CPh6-PEtOx solutions at $\mathrm{NaCl}$ concentration $c_{\text {salt }}=0.00730 \mathrm{M}$ and at $N$-PTS concentration $c_{\text {salt }}=0.00824 \mathrm{M}$.

Table 1. Values of $\left\langle t_{\mathrm{eq}}{ }^{(\mathrm{max})}>\right.$ for solutions of the studied polymer stars.

\begin{tabular}{|c|c|c|}
\hline \multirow{2}{*}{ Polymer } & \multicolumn{2}{|c|}{$t_{\mathrm{eq}}^{(\max )}, s$} \\
\hline & $\mathrm{NaCl}$ & $N$-PTS \\
\hline CPh6-PEtOz & 4500 & 3800 \\
\hline CPh6-PiPrOz & 8800 & 8000 \\
\hline CPh6-PEtOx & 3600 & 4200 \\
\hline CPh6-PiPrOx & 7500 & 8500 \\
\hline
\end{tabular}

On heating, a structural-phase transition was observed in solutions of star-shaped $\mathrm{CPh} 6-\mathrm{PAlOz}$ and $\mathrm{CPh} 6-\mathrm{PAlOx}$. Phase separation temperatures were measured by turbidimetry and light scattering methods (Figure 8). The temperature of its onset $T_{1}$ was determined as the beginning of the sharp decrease in optical transmittance $I^{*}$ and a rapid increase in the light scattering intensity $I$. At the temperature $T_{2}$, which reflects the finishing of phase separation, the optical transmission becomes zero. At this temperature, for most of the studied solutions, the intensity $I$ reaches maximum value. Note, that for the CPh6-PEtOx and CPh6-PEtOz solutions at low salt concentration $\left(c_{\text {salt }}<0.005 \mathrm{M}\right)$, the temperature $T_{2}$ could not be determined because it was too high $\left(>85^{\circ} \mathrm{C}\right)$.

As seen in Figure 8, with heating, the light scattering intensity began to change at relatively low temperatures. For example, for $\mathrm{CPh} 6-\mathrm{PEtOx}$ in $\mathrm{NaCl}$ solutions, a reliably measurable increase in $I$ was observed at $45^{\circ} \mathrm{C}$. At this temperature, the $I$ value exceeds the value of light scattering intensity $I$ at $21{ }^{\circ} \mathrm{C}\left(I_{21}\right)$ by $10 \%$, i.e., $I / I_{21}=1.1$. A further increase in $T$ leads to a slow increase in the $I$ value up to a temperature of onset of phase separation $T_{1}$ (for discussed solution, $70{ }^{\circ} \mathrm{C}$ according to turbidimetry data), at which $I / I_{21}=3.3$. Above $T_{1}$, the rate of change in the light scattering intensity on heating increases by an order of magnitude. The dependence of $I$ on $T$ is caused by the increase in the size $R_{\mathrm{S}}$ of large aggregates on heating, while the values of $R_{\mathrm{f}}$ and $R_{\mathrm{m}}$ do not change with temperature. (Figure 9). The change in $R_{\mathrm{S}}$ is not high, but it is detected rather reliably. Therefore, at $T<T_{1}$, the dominant process in the solutions of the studied star-shaped polymers was aggregation as a result of an increase in the dehydration degree of arms with temperature and the formation of intermolecular hydrogen bonds.

At $T>T_{1}$, a sharp increase in the size of large aggregates was observed, and at the temperature of the phase separation finishing, the $R_{\mathrm{s}}$ values reached hundreds of nanometers and even microns. Above $T_{2}$, the radii of large aggregates slightly decreased, which reflects the macromolecule compaction. Note that, in the studied temperature range, the sizes of micelle-like structures did not depend on temperature, and in the phase transition (near $T_{1}$ ) these particles ceased to be detected by the dynamic light scattering. Therefore, they joined with large aggregates or formed new supramolecular structures. 


\subsection{Influence of Salt Content on Phase Separation Temperatures}

Figure 10 shows the dependences of the phase separation temperature $T_{1}$ on the salt concentration $c_{\text {salt }}$ for water-salt solutions of CPh6-PAlOz and CPh6-PAlOx. It is clearly seen that the $\mathrm{NaCl}$ and $\mathrm{N}$-PTS affect the behavior of the investigated star-shaped pseudopolypeptoids in different ways. For $\mathrm{NaCl}$ solutions, an increase in $c_{\text {salt }}$ leads to a monotonic decrease in $T_{1}$, the rate of which decreases in the region of high values of $c_{\text {salt }}$. Similar dependences were observed earlier for PAlOx of different architectures [69,83-87], as well as linear and star-shaped PEtOz [60]. In the case of N-PTS solutions, for all polymers, the phase separation temperatures decline very quickly in the region of low salt content. At a concentration $c_{\text {salt }}$ corresponding to approximately one N-PTS molecule per one arm of polymer star, the decrease in $T_{1}$ slows down, the phase separation temperature reaches a minimum value $T_{1}{ }^{(\mathrm{min})}$, and then the $T_{1}$ value begins to rise with increasing $\mathrm{N}$-PTS content. Thus, for the studied polymer stars, at a low content in solution, $N$-PTS manifests itself as a kosmotropic agent, and at high $c_{\text {salt }}, N$-PTS exerts chaotropic activity. What agent, chaotropic or kosmotropic, is a particular salt is a complex problem and its analysis, in particular the study of the interaction of thermoresponsive polymers with salt, has been devoted to a large number of works $[66,67,71,72,88-90]$. Analyzing the effect of salt on the behavior of polymer solution, it is necessary to take into account not only the chemical structure of the polymer and salt, but also their concentration in solution, ionic strength, temperature, etc.
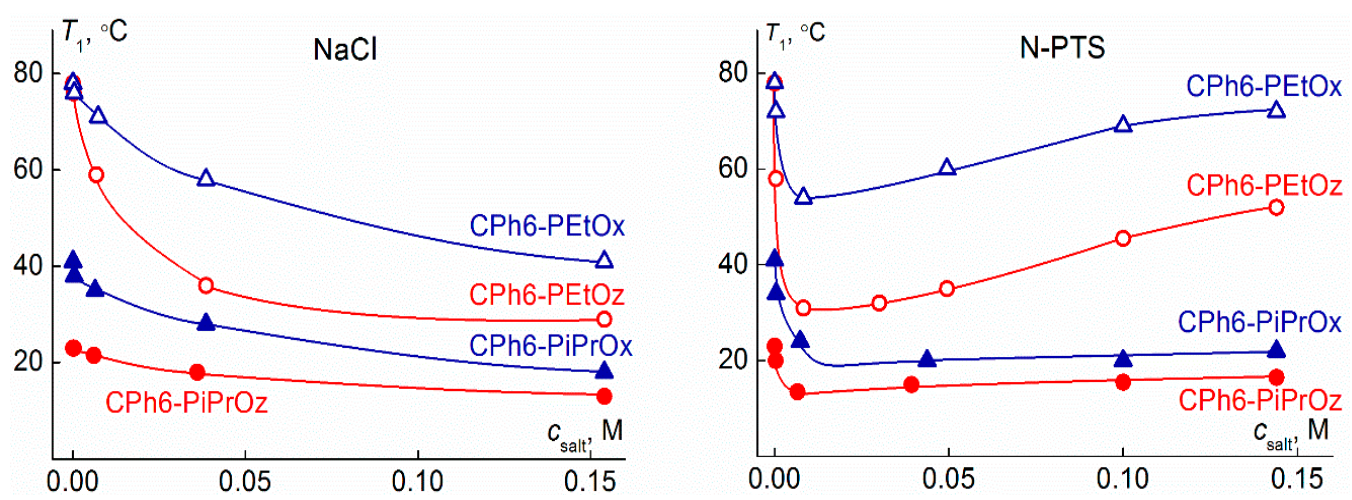

Figure 10. Dependencies of the phase separation temperature $T_{1}$ on salt concentration $c_{\text {salt }}$ for star-shaped CPh6-PAlOz and CPh6-PAlOx in $\mathrm{NaCl}$ and $\mathrm{N}$-PTS solutions.

The effect of $\mathrm{NaCl}$ and $\mathrm{N}$-PTS on the behavior of CPh6-PAlOz and CPh6-PAlOx solutions depends on the arm structure. It is convenient to analyze the effect of the chemical structure of arms on the characteristics of water-salt solutions of the studied stars, comparing not only the dependences of the phase separation temperatures on the salt content (Figure 10), but also the dependences $\Delta T_{1}=T_{1}{ }^{(0)}-T_{1}{ }^{(\mathrm{c})}$ on $c_{\text {salt }}$ (Figure 11), where $T_{1}{ }^{(0)}$ is the temperature of onset of phase separation at $c_{\text {salt }}=0$ and $T_{1}{ }^{(c)}$ is this temperature at a given $c_{\text {salt }}$. The $\Delta T_{1}$ value determines the change in the phase separation temperature upon salt addition. As can be seen in Figure 10, for both salts in the studied range of $c_{\text {salt }}$, the phase separation temperatures decrease in the series CPh6-PEtOx-CPh6-PEtOz$\mathrm{CPh} 6-\mathrm{PiPrOx}-\mathrm{CPh} 6-\mathrm{PiPrOz}$. Therefore, in water-salt solutions, a regularity, which is valid for solutions of CPh6-PAlOz and CPh6-PAlOx in water, is preserved. The $\Delta T_{1}$ values in $\mathrm{NaCl}$ solutions change in the same way (Figure 11). In solutions containing N-PTS, this sequence occurs only at low $c_{\text {salt }}$ concentrations (Figure 11). At $c_{\text {salt }}>0.02 \mathrm{M}$, the $\Delta T_{1}$ value for $\mathrm{CPh} 6-\mathrm{PEtOz}$ becomes lower than the corresponding characteristic for $\mathrm{CPh} 6-\mathrm{PiPrOx}$. This is due to the fact that after reaching the minimum value $T_{1}(\mathrm{~min})$, the phase separation temperature for stars containing side ethyl and isopropyl groups in the arms increases with different rates. For CPh6-PEtOz and $\mathrm{CPh} 6-\mathrm{PEtOx}$, the temperature $T_{1}$ at high $c_{\text {salt }}$ exceeded the value $T_{1}{ }^{(\mathrm{min})}$ by 29 and $18{ }^{\circ} \mathrm{C}$, respectively. For CPh6-PiPrOx and CPh6-PiPrOz, the 
increase in $T_{1}$ in the region of high $N$-PTS content was smoother, and the change in $T_{1}$ did not exceed $4{ }^{\circ} \mathrm{C}$ (Figure 11).
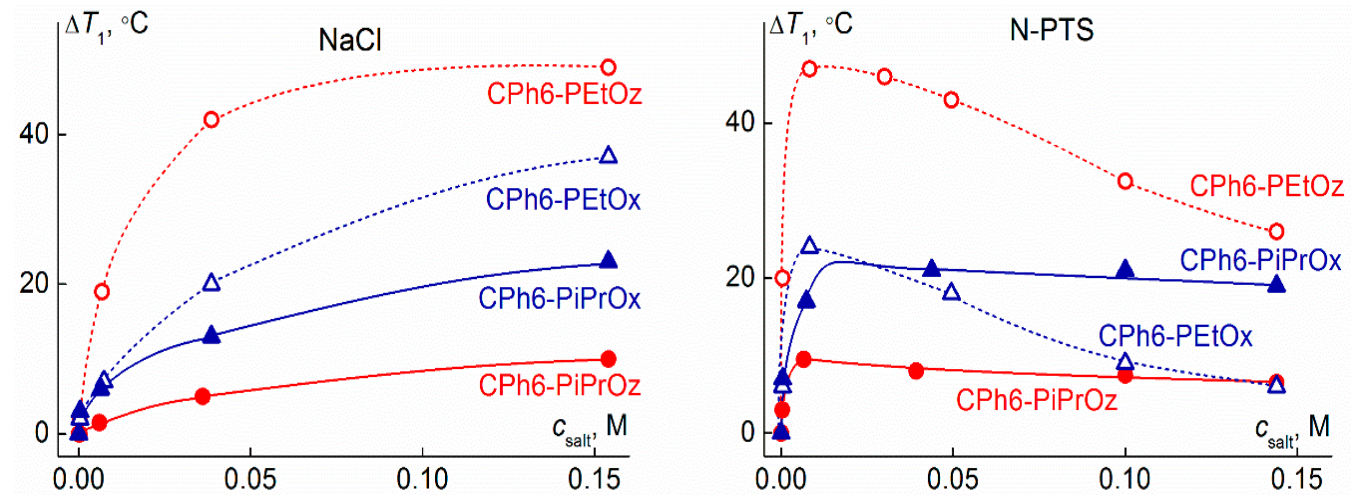

Figure 11. Dependencies of $\Delta T_{1}$ on salt concentration $c_{\text {salt }}$ for star-shaped CPh6-PAlOz and CPh6$\mathrm{PAlOx}$ in $\mathrm{NaCl}$ and $\mathrm{N}$-PTS solutions.

As is known, with the same structure of side groups, $\mathrm{PAlOz}$ are more hydrophobic than PAlOx. Accordingly, at the given concentration and molar mass of the polymer, the phase separation temperatures for aqueous solutions of $\mathrm{PAlOz}$ are lower than for the corresponding PAlOx [14,43,91]. This regularity is observed for water-salt solutions of the studied star-shaped polymers, namely, at all salt concentrations $c_{\text {salt }}$ in N-PTS and $\mathrm{NaCl}$ solutions, the temperature $T_{1}$ decreased with passage from $\mathrm{CPh} 6-\mathrm{PAlOx}$ to $\mathrm{CPh} 6-$ $\mathrm{PAlOz}$. Note that the molar masses of the CPh6-PAlOz samples are higher than the MM of CPh6-PAlOx. An increase in the MM usually leads to a growth in the phase separation temperatures $[85,92-94]$. Consequently, some contribution to the observed difference in the $T_{1}$ values for water-salt solutions star-shaped of CPh6-PAlOz and CPh6-PAlOx can be made by changing MM.

As seen in Figure 11, for the star-shaped CPh6-PEtOz, the maximum change in the phase separation temperature $\Delta T_{1}$ is approximately the same in both water-salt solvents: The maximum $\Delta T_{1}$ value is around $45^{\circ} \mathrm{C}$. For $\mathrm{CPh} 6$ - $\mathrm{PiPrOz}$, the maximum $\Delta T_{1}$ values are noticeably lower $\left(\Delta T_{1} \sim 10{ }^{\circ} \mathrm{C}\right)$, but they also coincide in different solvents. In the case of $\mathrm{CPh} 6-\mathrm{PAlOx}$, a similar behavior was detected for $\mathrm{CPh} 6-\mathrm{PiPrOx}$, while for $\mathrm{CPh}$-PEtOx, the maximum $\Delta T_{1}$ values in $\mathrm{NaCl}$ and $\mathrm{N}$-PTS solutions differed by $10^{\circ} \mathrm{C}$.

Comparison of the obtained results with the literature data for other star-shaped pseudo-polypeptoids shows that their behavior in water-salt solutions depends on the core structure. For example, for water-salt solutions of eight-arm star-shaped poly-2-isopropyl2-oxazoline with calix [8] arene core (at polymer concentration $c=0.0050 \mathrm{~g} \cdot \mathrm{cm}^{-3}$ ), the dependence of the phase separation temperature on the N-PTS content was monotonic [70], and the decrease in $T_{1}$ in the $c_{\text {salt }}$ range from $0-0.06 \mathrm{M}$ was about $4{ }^{\circ} \mathrm{C}$. Note that for the $\mathrm{CPh} 6-\mathrm{PiPrOx}$ studied in this work, the $\Delta T_{1}$ value exceeded $20^{\circ} \mathrm{C}$.

Figure 12 compares the dependences of $\Delta T_{1}$ on $c_{\text {salt }}$ for the six-arm CPh6-PEtOz and CPh6-PiPrOx studied in this work, four-arm PEtOz with a calix [4] arene core (C4APEtOz) [60], and eight-arm PiPrOx with calix [8] arene core (C8A-PiPrOx) [69]. For six- and four-arm $\mathrm{PEtOz}$, the considered dependences differ insignificantly, and only in the region of high $\mathrm{NaCl}$ content, the $\Delta T_{1}$ value for CPh6-PEtOz is noticeably higher than $\Delta T_{1}$ for C4A-PEtOz. For star-shaped PiPrOx at all concentrations, the $\Delta T_{1}$ value for the polymer with $\mathrm{CPh} 6$ core is higher than for the star with $\mathrm{C} 8 \mathrm{~A}$. These facts suggest that star-shaped pseudo-polypeptoids with a hexaaza[ $2_{6}$ ] orthoparacyclophane core are more sensitive to the presence of $\mathrm{NaCl}$ than similar stars with a calix[n]arene core. However, it should be remembered that the compared polymers differed not only in the structure of the branching center, but also in the number and length of arms. The values of the latter characteristics determine the intramolecular density of the macromolecule, and, accordingly, the accessibility of the core for solvent molecules and molecules of low molecular weight salts. 


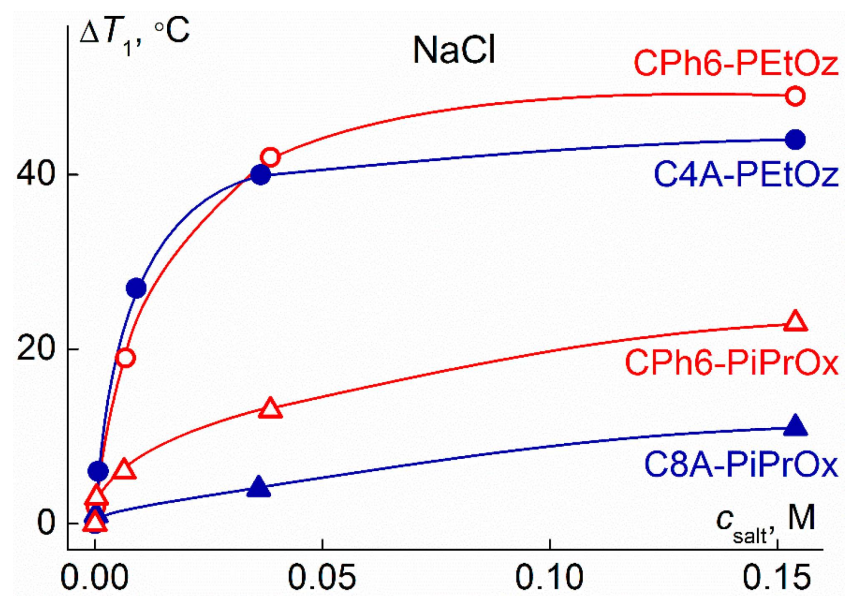

Figure 12. Dependencies $\Delta T_{1}$ on $\mathrm{NaCl}$ concentration $c_{\text {salt }}$ for $\mathrm{CPh} 6-\mathrm{PEtOz}, \mathrm{CPh} 6-\mathrm{PiPrOx}, \mathrm{C} 4 \mathrm{~A}-\mathrm{PEtOz}$, and C8A-PiPrOx at $c=0.0050 \mathrm{~g} \cdot \mathrm{cm}^{-2}$.

\section{Conclusions}

The effect of $\mathrm{NaCl}$ and $\mathrm{N}$-PTS on the self-organization in aqueous solutions of sixarm star-shaped $\mathrm{CPh} 6-\mathrm{PAlOz}$ and $\mathrm{CPh} 6-\mathrm{PAlOx}$ and on phase separation temperatures were investigated. It was shown that in the case of $\mathrm{CPh} 6-\mathrm{PAlOx}$ at low temperatures, the addition of salts does not lead to significant changes in the solution characteristics. A different situation took place for $\mathrm{CPh} 6-\mathrm{PAlOz}$, in solutions of which, with a salt content corresponding to approximately one salt molecule per arm of star, the set of scattering objects changed. At this concentration, the micelle-like structures appeared in solutions, and isolated molecules ceased to be detected by dynamic light scattering. The observed effect depended on the arm structure. In CPh6-PEtOz solutions, micelle-like aggregates appeared with the addition of both salts, while in $\mathrm{CPh} 6-\mathrm{PiPrOz}$ solutions they formed only with $\mathrm{N}$-PTS addition. In $\mathrm{NaCl}$ solutions of $\mathrm{CPh} 6-\mathrm{PiPrOz}$, macromolecules and large aggregates were present in solutions at all studied salt concentrations. The effect of the salt structure was traced in the fact that in most N-PTS solutions the sizes of the aggregates were constant, while in $\mathrm{NaCl}$ solutions they increased with growth of salt concentration.

On heating, a phase transition with the formation of supramolecular micron-sized structures was observed in all the studied water-salt solutions of the star-shaped CPh6$\mathrm{PAlOz}$ and CPh6-PAlOx. As well as in aqueous solutions, in both used solvents, at the same salt concentration, the phase separation temperature decreased in the series $\mathrm{CPh} 6$ PEtOx-CPh6-PEtOz-CPh6-PiPrOx-CPh6-PiPrOz. This is caused by an increase in the hydrophobicity of the polymers both with growth of the size of the side radical in the arms and with an elongation of the monomer unit by one $-\mathrm{CH}_{2}-$ group.

The effect of the structure of salt and polymer on the phase separation temperature $T_{1}$ was found. For all the stars studied, the temperature $T_{1}$ monotonically decreased with increase in $\mathrm{NaCl}$ content in solution from $c_{\text {salt }}=0$ to $0.154 \mathrm{M}$. This reduction for CPh6-PEtOz and CPh6-PEtOx polymers reached 49 and $37^{\circ} \mathrm{C}$, respectively. For more hydrophobic stars with isopropyl side groups, the discussed change was much smaller, $23^{\circ} \mathrm{C}$ for $\mathrm{CPh} 6$ - $\mathrm{PiPrOx}$ and $11{ }^{\circ} \mathrm{C}$ for $\mathrm{CPh} 6-\mathrm{PiPrOz}$. In N-PTS solutions for all polymers, the dependence of the phase separation temperature on the salt concentration was non-monotonic. In the region of low salt content, $T_{1}$ decreased sharply, reaching a minimum value at concentration $c_{\text {salt }}$ corresponding to approximately one N-PTS molecule per one arm of a polymer star. Above this concentration, an increase in the phase separation temperature was observed. As well as in $\mathrm{NaCl}$ solutions, in solutions with the addition of $N$-PTS, the maximum change in $T_{1}$ was greater for polymers with ethyl side radicals. Comparison of the obtained results with the literature data for star-shaped pseudo-polypeptoids with a calix[n]arene branching center showed that $\mathrm{PAlOz}$ and PAlOx stars with a hexaaza[2 $\left.2_{6}\right]$ orthoparacyclophane core are more sensitive to the presence of salt in solution. 
Author Contributions: Conceptualization, A.F.; methodology, A.T.; writing-original draft preparation, A.T., A.F. and T.K.; formal analysis, A.T. and T.K.; investigation, T.K., A.R. and A.S.; resources, A.S.; data curation, A.S.; writing-review and editing, A.S. and A.R.; visualization, T.K.; supervision, A.F.; project administration, A.F.; funding acquisition, T.K. All authors have read and agreed to the published version of the manuscript.

Funding: This research was funded by the Russian Science Foundation, grant number 19-73-00175.

Institutional Review Board Statement: Not applicable.

Informed Consent Statement: Not applicable.

Data Availability Statement: Not applicable.

Conflicts of Interest: The authors declare no conflict of interest.

\section{References}

1. Zahoranova, A.; Luxenhofer, R. Poly(2-oxazoline)-and poly(2-oxazine)-based self-assemblies, polyplexes, and drug nanoformulations-an update. Adv. Healthc. Mater. 2021, 10, 2001382. [CrossRef]

2. Dimitrov, I.; Trzebicka, B.; Müller, A.H.E.; Dworak, A.; Tsvetanov, C.B. Thermosensitive water-soluble copolymers with doubly responsive reversibly interacting entities. Prog. Polym. Sci. 2007, 32, 1275-1343. [CrossRef]

3. Aseyev, V.; Tenhu, H.; Winnik, F. Non-ionic thermoresponsive polymers in water. Adv. Polym. Sci. 2011, 242, $29-89$.

4. Seuring, J.; Agarwal, S. Polymers with upper critical solution temperature in aqueous solution. Macromol. Rapid Commun. 2012, 33, 1898-1920. [CrossRef]

5. Vancoillie, G.; Frank, D.; Hoogenboom, R. Thermoresponsive poly(oligo ethylene glycol acrylates). Prog. Polym. Sci. 2014, 39, 1074-1095. [CrossRef]

6. Gangloff, N.; Ulbricht, J.; Lorson, T.; Schlaad, H.; Luxenhofer, R. Peptoids and polypeptoids at the frontier of supr- and mcromolecular engineering. Chem. Rev. 2016, 116, 1753-1802. [CrossRef]

7. Kwon, G.; Suwa, S.; Yokoyama, M.; Okano, T.; Sakurai, Y.; Kataoka, K. Enhanced tumor accumulation and prolong circulation times of micelle-forming poly(ethylene-oxide-aspartate)block copolymer-adriamycin conjugates. J. Control. Release 1994, 29, 17-23. [CrossRef]

8. Allen, C.; Maysinger, D.; Eisenberg, A. Nano-engineering block copolymer aggregates for drug delivery. Colloids Surf. B. 1999, 16, 3-27. [CrossRef]

9. Kataoka, K.; Harada, A.; Nagasaki, Y. Block copolymer micelles for drug delivery: Design, characterization and biological significance. Adv. Drug Deliv. Rev. 2001, 47, 113-131. [CrossRef]

10. Islam, M.R.; Lu, Z.Z.; Li, X.; Sarker, A.K.; Hu, L.; Choi, P.; Li, X.; Hakobyan, N.; Serpe, M.J. Responsive polymers for analytical applications: A review. Anal. Chim. Acta 2013, 789, 17-32. [CrossRef]

11. Gandhi, A.; Paul, A.; Sen, S.O.; Sen, K.K. Studies on thermoresponsive polymers: Phase behaviour, drug delivery and biomedical applications. Asian J. Pharm. Sci. 2015, 10, 99-107. [CrossRef]

12. Wu, W.; Wang, W.; Li, J. Star polymers: Advances in biomedical applications. Prog. Polym. Sci. 2015, 46, 55-85. [CrossRef]

13. Vdovchenko, A.A.; Hubina, A.V.; Vlakh, E.G.; Tennikova, T.B. Self-assembled polymer particles based on thermoresponsive biodegradable copolymers of amino acids. Mendeleev Commun. 2017, 27, 153-154. [CrossRef]

14. Sedlacek, O.; Hoogenboom, R. Drug delivery systems based on poly(2-oxazoline)s and poly(2-oxazine)s. Adv. Therap. 2020, 3, 1900168. [CrossRef]

15. Tomalia, D.A.; Sheetz, D.P. Homopolymerization of 2-alkyl- and 2-aryl-2-oxazolines. J. Polym. Sci. Part A Polym. Chem. 1966, 4 , 2253-2265. [CrossRef]

16. Seeliger, W.; Aufderhaar, E.; Diepers, W.; Feinauer, R.; Nehring, R.; Thier, W.; Hellmann, H. Recent syntheses and reactions of cyclic imidic esters. Angew. Chem. Int. Ed. 1966, 5, 875-888. [CrossRef] [PubMed]

17. Kagiya, T.; Narisawa, S.; Maeda, T.; Fukui, K. Ring-opening polymerization of 2-substituted 2-oxazolines. J. Polym. Sci. Part B Polym. Lett. 1966, 4, 441-445. [CrossRef]

18. Bassiri, T.G.; Levy, A.; Litt, M. Polymerization of cyclic imino ethers. I. Oxazolines. J. Polym. Sci. Part B Polym. Lett. 1967, 5, 871-879. [CrossRef]

19. Levy, A.J.; Litt, M.H. Polymerization of cyclic imino ethers. II. Oxazines. J. Polym. Sci. Polym. Lett. Ed. 1967, 5, 881-886. [CrossRef]

20. Kobayashi, S.; Igarashi, T.; Moriuchi, Y.; Saegusa, T. Block copolymers from cyclic imino ethers: A new class of nonionic polymer surfactant. Macromolecules 1986, 19, 535-541. [CrossRef]

21. Lambermont-Thijs, H.M.L.; Fijten, M.W.M.; van der Linden, A.J.T.; van Lankvelt, B.M.; Bloksma, M.M.; Schubert, U.S.; Hoogenboom, R. Efficient cationic ring-opening polymerization of diverse cyclic imino ethers: Unexpected copolymerization behavior. Macromolecules 2011, 44, 4320-4325. [CrossRef]

22. Kempe, K. Chain and step growth polymerizations of cyclic imino ethers: From poly(2-oxazoline)s to poly(ester amide)s. Macromol. Chem. Phys. 2017, 218, 1700021. [CrossRef] 
23. Weber, C.; Wagner, M.; Baykal, D.; Hoeppener, S.; Paulus, R.M.; Festag, G.; Altuntas, E.; Schacher, F.H.; Schubert, U.S. Easy access to amphiphilic heterografted poly(2-oxazoline) comb copolymers. Macromolecules 2013, 46, 5107-5116. [CrossRef]

24. Luxenhofer, R.; Bezen, M.; Jordan, R. Kinetic investigations on the polymerization of 2-oxazolines using pluritriflate initators. Macromol. Rapid Commun. 2008, 29, 1509-1513. [CrossRef]

25. Hoogenboom, R.; Schlaad, H. Thermoresponsive poly(2-oxazoline)s, polypeptoids, and polypeptides. Polym. Chem. 2017, 8, 24-40. [CrossRef]

26. Dworak, A.; Trzebicka, B.; Kowalczuk, A.; Tsvetanov, C.; Rangelov, S. Polyoxazolines-mechanism of synthesis and solution properties. Polymery 2014, 59, 88-94. [CrossRef]

27. Glassner, M.; D’hooge, D.R.; Park, J.; van Steenberge, P.H.; Monnery, B.D.; Reyniers, M.-F.; Hoogenboom, R. Systematic investigation of alkyl sulfonate initiators for the cationic ring-opening polymerization of 2-oxazolines revealing optimal combinations of monomers and initiators. Eur. Polym. J. 2015, 65, 298-304. [CrossRef]

28. Glassner, M.; Vergaelen, M.; Hoogenboom, R. Poly(2-oxazoline)s: A comprehensive overview of polymer structures and their physical properties. Polym. Int. 2018, 67, 32-45. [CrossRef]

29. Men, Y.; Schlaad, H.; Yuan, J. Cationic poly(ionic liquid) with tunable lower critical solution temperature-type phase transition. ACS Macro Lett. 2013, 2, 456-459. [CrossRef]

30. Vacogne, C.D.; Schopferer, M.; Schlaad, H. Physical gelation of $\alpha$-helical copolypeptides. Biomacromolecules 2016, 17, $2384-2391$. [CrossRef]

31. Bogomolova, A.; Secker, C.; Koetz, J.; Schlaad, H. Thermo-induced multistep assembly of double-hydrophilic block copolypeptoids in water. Colloid Polym. Sci. 2017, 295, 1305-1312. [CrossRef]

32. Oleszko-Torbus, N.; Wałach, W.; Utrata-Wesołek, A.; Dworak, A. Control of the crystalline properties of 2-isopropyl-2-oxazoline copolymers in condensed state and in solution depending on the composition. Macromolecules 2017, 50, 7636-7645. [CrossRef]

33. Grube, M.; Leiske, M.N.; Schubert, U.S.; Nischang, I. POx as an alternative to PEG? A hydrodynamic and light scattering study. Macromolecules 2018, 51, 19051916. [CrossRef]

34. Lukyanenko, N.G.; Pastushok, V.N.; Bordunov, A.V.; Vetrogon, V.I.; Vetrogon, N.I.; Bradshaw, J.S. New phenol-containing bis(azacrown ether)s: Synthesis and complexing properties. J. Chem. Soc. Perkin Trans. 1 1994, 11, 1489-1493. [CrossRef]

35. Simion, C.; Gherase, D.; Sima, S.; Simion, A.M. Serendipitous synthesis of a cyclic formamidine. Application to the synthesis of polyazamacrocycles. Comptes Rendus Chim. 2015, 18, 611-613. [CrossRef]

36. Rakhimova, E.B.; Ismagilov, R.A.; Ibragimov, A.G. Synthesis and fungicidal activity of bis-1,5,3-dithiazepanes and crown-like macroheterocycles. Russ. J. Gener. Chem. 2019, 89, 1591-1594. [CrossRef]

37. Brusentzeva, O.I.; Kharitonov, Y.V.; Fadeev, D.S.; Shults, E.E. Synthesis and spectroscopic studies of furan-bridged polyazamacrocycles through 15,16-bis((prop-2-ynylamino)methyl)labdatriene transformations. J. Incl. Phenom. Macrocycl. Chem. 2020, 96, 245-250. [CrossRef]

38. Morgese, G.; Verbraeken, B.; Ramakrishna, N.R.; Gombert, Y.; Cavalli, E.; Rosenboom, J.G.; Zenobi-Wong, M.; Spencer, N.D.; Hoogenboom, R. Chemical design of non-ionic polymer brushes as biointerfaces: Poly(2-oxazine)s outperform both poly(2oxazoline)s and PEG. Angew. Chem. Int. Ed. 2018, 57, 11667-11672. [CrossRef] [PubMed]

39. Bloksma, M.M.; Schubert, U.S.; Hoogenboom, R. Poly(cyclic imino ether)s beyond 2-substituted-2-oxazolines. Macromol. Rapid Commun. 2011, 32, 1419-1441. [CrossRef] [PubMed]

40. Sinnwell, S.; Ritter, H. Microwave accelerated polymerization of 2-phenyl-5,6-dihydro-4H-1,3-oxazine: Kinetics and influence of end-groups on glass transition temperature. Macromol. Rapid Commun. 2006, 27, 1335-1340. [CrossRef]

41. Lübtow, M.M.; Hahn, L.; Haider, M.S.; Luxenhofer, R. Drug specificity, synergy and antagonism in ultrahigh capacity poly(2oxazoline)/poly(2-oxazine) based formulations. J. Am. Chem. Soc. 2017, 139, 10980-10983. [CrossRef] [PubMed]

42. Bloksma, M.M.; Paulus, R.M.; van Kuringen, H.P.; van der Woerdt, F.; Lambermont-Thijs, H.M.; Schubert, U.S.; Hoogenboom, R. Thermoresponsive poly(2-oxazine)s. Macromol. Rapid Commun. 2012, 33, 92-96. [CrossRef] [PubMed]

43. Haider, M.S.; Lübtow, M.M.; Endres, S.; Forster, S.; Flegler, V.J.; Böttcher, B.; Aseyev, V.; Pöppler, A.-C.; Luxenhofer, R. Think beyond the core: Impact of the hydrophilic corona on drug solubilization using polymer micelles. ACS Appl. Mater. Interfaces 2020, 12, 24531-24543. [CrossRef]

44. Schlaad, H.; Diehl, C.; Gress, A.; Meyer, M.; Demirel, A.L.; Nur, Y.; Bertin, A. Poly(2-oxazoline)s as smart bioinspired polymers. Macromol. Rapid Commun. 2010, 31, 511-525. [CrossRef] [PubMed]

45. Roy, D.; Brooks, W.L.A.; Sumerlin, B.S. New directions in thermoresponsive polymers. Chem. Soc. Rev. 2013, 42, 7214-7243. [CrossRef] [PubMed]

46. Luef, K.P.; Petit, C.; Ottersbock, B.; Oreski, G.; Ehrenfeld, F.; Grassl, B.; Reynaud, S.; Wiesbrock, F. UV-mediated thiol-ene click reactions for the synthesis of drug-loadable and degradable gels based on copoly(2-oxazoline)s. Eur. Polym. J. 2017, 88, 701-712. [CrossRef] [PubMed]

47. Schenk, V.; Rossegger, E.; Ebner, C.; Bangerl, F.; Reichmann, K.; Hoffmann, B.; Höpfner, M.; Wiesbrock, F. RGD-functionalization of poly(2-oxazoline)-based networks for enhanced adhesion to cancer cells. Polymers 2014, 6, 264-279. [CrossRef]

48. Kempe, K.; Vollrath, A.; Schaefer, H.W.; Poehlmann, T.G.; Biskup, C.; Hoogenboom, R.; Hornig, S.; Schubert, U.S. Multifunctional poly(2-oxazoline) nanoparticles for biological applications. Macromol. Rapid Commun. 2010, 31, 1869-1873. [CrossRef]

49. Dargaville, T.R.; Forster, R.; Farrugia, B.L.; Kempe, K.; Voorhaar, L.; Schubert, U.S.; Hoogenboom, R. Poly(2-oxazoline) hydrogel monoliths via thiol-ene coupling. Macromol. Rapid Commun. 2012, 33, 1695-1700. [CrossRef] [PubMed] 
50. Zardad, A.-Z.; Essop, C.Y.; Du Toit, L.C.; Kumar, P.; Mabrouk, M.; Kondiah, P.P.D.; Pillay, V. A review of thermo-and ultrasoundresponsive polymeric systems for delivery of chemotherapeutic agents. Polymers 2016, 8, 359. [CrossRef] [PubMed]

51. Kuckling, D.; Wycisk, A. Stimuli-responsive star polymers. J. Polym. Sci. Part A Polym. Chem. 2013, 51, 2980-2994. [CrossRef]

52. Xu, W.; Choi, I.; Plamper, F.A.; Synatschke, C.V.; Müller, A.H.E.; Melnichenko, Y.B.; Tsukruk, V.V. Thermo-induced limited aggregation of responsive star polyelectrolytes. Macromolecules 2014, 47, 2112-2121. [CrossRef]

53. Kowalczuk, A.; Kronek, J.; Bosowska, K.; Trzebicka, B.; Dworak, A. Star poly(2-ethyl-2-oxazoline)s-synthesis and thermosensitivity. Polym. Int. 2011, 60, 1001-1009. [CrossRef]

54. Amirova, A.; Golub, O.; Kirila, T.; Razina, A.; Tenkovtsev, A.; Filippov, A. Influence of arm length on aqueous solution behavior of thermosensitive poly(2-isopropyl-2-oxazoline) stars. Colloid Polym. Sci. 2017, 295, 117-124. [CrossRef]

55. Amirova, A.; Rodchenko, S.; Milenin, S.; Tatarinova, E.; Kurlykin, M.; Tenkovtsev, A.; Filippov, A. Influence of a hydrophobic core on thermoresponsive behavior of dendrimer-based star-shaped poly(2-isopropyl-2-oxazoline) in aqueous solutions. J. Polym. Res. 2017, 24, 124. [CrossRef]

56. Kirila, T.Y.; Kurlykin, M.P.; Tenkovtsev, A.V.; Filippov, A.P. Behavior of aqueous solutions of thermosensitive starlike polyalkyloxazolines with different arm structures. Polym. Sci. A 2017, 59, 826-838. [CrossRef]

57. Sezonenko, T.; Qiu, X.-P.; Winnik, F.M.; Sato, T. Dehydration, micellization, and phase separation of thermosensitive polyoxazoline star block copolymers in aqueous solution. Macromolecules 2019, 52, 935-944. [CrossRef]

58. Kirila, T.U.; Smirnova, A.V.; Filippov, A.S.; Razina, A.B.; Tenkovtsev, A.V.; Filippov, A.P. Thermosensitive star-shaped poly-2ethyl-2-oxazine. Synthesis, structure characterization, conformation, and self-organization in aqueous solutions. Eur. Polym. J. 2019, 120, 109-215. [CrossRef]

59. Kirila, T.; Smirnova, A.; Razina, A.; Tenkovtsev, A.; Filippov, A. Synthesis and conformational characteristics of thermosensitive star-shaped six-arm polypeptoids. Polymers 2020, 12, 800. [CrossRef] [PubMed]

60. Smirnova, A.V.; Kirila, T.Y.; Dudkina, M.M.; Tenkovtsev, A.V.; Filippov, A.P. Influence molecular architecture on behavior of thermoresponsive poly-2-ethyl-2-oxazine in saline media. Mendeleev Commun. 2020, 30, 802-804. [CrossRef]

61. Viegas, T.X.; Bentley, M.D.; Harris, J.M.; Fang, Z.; Yoon, K.; Dizman, B.; Weimer, R.; Mero, A.; Pasut, G.; Veronese, F.M. Polyoxazoline: Chemistry, properties, and applications in drug delivery. Bioconjug. Chem. 2011, 22, 976-986. [CrossRef]

62. Zhang, P.; Qian, X.; Zhang, Z.; Li, C.; Xie, C.; Wu, W.; Jiang, X. Supramolecular amphiphilic polymer-based micelles with seven-armed polyoxazoline coating for drug delivery. ACS Appl. Mater. Interfaces 2017, 9, 5768-5777. [CrossRef] [PubMed]

63. Chen, W.; Zhou, S.; Ge, L.; Wu, W.; Jiang, X. Translatable high drug loading drug delivery systems based on biocompatible polymer nanocarriers. Biomacromolecules 2018, 19, 1732-1745. [CrossRef] [PubMed]

64. Sano, K.; Kanada, Y.; Takahashi, K.; Ding, N.; Kanazaki, K.; Mukai, T.; Ono, M.; Saji, H. Enhanced delivery of radiolabeled polyoxazoline into tumors via self-aggregation under hyperthermic conditions. Mol. Pharm. 2018, 15, 3997-4003.

65. Aseyev, V.; Tenhu, H.; Winnik, F.M. Self Organized Nanostructures of Amphiphilic Block Copolymers II; Muller, A.H.E., Borisov, O., Eds.; Springer: Berlin, Germany, 2011; pp. 29-89.

66. Heyda, J.; Dzubiella, J. Thermodynamic description of hofmeister effects on the LCST of thermosensitive polymers. J. Phys. Chem. B 2014, 118, 10979-10988. [CrossRef]

67. Eeckman, F.; Amighi, K.; Moes, A.J. Effect of some physiological and non-physiological compounds on the phase transition temperature of thermoresponsive polymers intended for oral controlled-drug delivery. Int. J. Pharm. 2001, 222, 259-270. [CrossRef]

68. Zhang, Y.; Cremer, P.S. Chemistry of hofmeister anions and osmolytes. Annu. Rev. Phys. Chem. 2010, 61, 63-83. [CrossRef]

69. Amirova, A.I.; Blokhin, A.N.; Razina, A.B.; Tenkovtsev, A.V.; Filippov, A.P. The behavior of thermoresponsive star-shaped poly-2-isopropyl-2-oxazoline in saline media. Mendeleev Commun. 2019, 29, 472-474.

70. Amirova, A.I.; Kirila, T.U.; Blokhin, A.N.; Razina, A.B.; Bursian, A.E.; Tenkovtsev, A.V.; Filippov, A.P. Influence of hydrophilic and hydrophobic low-molecular-weight compounds on the thermoresponsiveness of star-shaped poly-2-isopropyl-2-oxazoline in solutions. Mendeleev Commun. 2020, 30, 502-504. [CrossRef]

71. Zhao, H. Are ionic liquids kosmotropic or chaotropic? An evaluation of available thermodynamic parameters for quantifying the ion kosmotropicity of ionic liquids. J. Chem. Technol. Biotechnol. 2006, 81, 877-891. [CrossRef]

72. Zhao, H.; Olubajo, O.; Song, Z.; Sims, A.L.; Person, T.E.; Lawal, R.A.; Holley, L.D.A. Effect of kosmotropicity of ionic liquids on the enzyme stability in aqueous solutions. Bioorg. Chem. 2006, 34, 15-25. [CrossRef]

73. Moghaddam, S.Z.; Thormann, E. The Hofmeister series: Specific ion effects in aqueous polymer solutions. J. Colloid Interface Sci. 2019, 555, 615-635. [CrossRef] [PubMed]

74. Abezgauz, L.; Kuperkar, K.; Hassan, P.A.; Ramon, O.; Bahadur, P.; Danino, D. Effect of Hofmeister anions on micellization and micellar growth of the surfactant cetylpyridinium chloride. J. Colloid Interface Sci. 2010, 342, 83-92. [CrossRef] [PubMed]

75. Rossegger, E.; Schenk, V.; Wiesbrock, F. Design strategies for functionalized poly(2-oxazoline)s and derived materials. Polymers 2013, 5, 956-1011. [CrossRef]

76. Weber, C.; Hoogenboom, R.; Schubert, U.S. Temperature responsive bio-compatible polymers based on poly(ethylene oxide) and poly(2-oxazoline)s. Prog. Polym. Sci. 2012, 37, 686-714. [CrossRef]

77. Trinh, L.T.T.; Lambermont-Thijs, H.M.L.; Schubert, U.S.; Hoogenboom, R.; Kjøniksen, A.L. Thermoresponsive poly(2-oxazoline) block copolymers exhibiting two cloud points: Complex multistep assembly behavior. Macromolecules 2012, 45, $4337-4345$. [CrossRef] 
78. Steinschulte, A.A.; Schulte, B.; Rütten, S.; Eckert, T.; Okuda, J.; Möller, M.; Schneider, S.; Borisov, O.V.; Plamper, F.A. Effects of architecture on the stability of thermosensitive unimolecular micelles. Phys. Chem. Chem. Phys. 2014, 16, 4917-4932. [CrossRef]

79. Kirila, T.; Smirnova, A.; Kurlykin, M.; Tenkovtsev, A.; Filippov, A. Self-organization in aqueous solutions of thermosensitive star-shaped and linear gradient copolymers of 2-ethyl-2-oxazoline and 2-isopropyl-2-oxazoline. Colloid. Polym. Sci. 2020, 298, 535-546. [CrossRef]

80. Kirile, T.Y.; Tobolina, A.I.; Elkina, A.A.; Kurlykin, M.P.; Tenkovtsev, A.V.; Filippov, A.P. Self-assembly processes in aqueous solutions of eat-sensitive star-shaped poly-2-ethyl-2-oxazoline. Fiber Chem. 2018, 50, 248-251. [CrossRef]

81. Smirnova, A.V.; Kirila, T.U.; Kurlykin, M.P.; Tenkovtsev, A.V.; Filippov, A.P. Behavior of aqueous solutions of polymer star with block copolymer poly(2-ethyl-2-oxazoline) and poly(2-isopropyl-2-oxazoline) arms. Int. J. Polym. Anal. Charact. 2017, 22, 677-684. [CrossRef]

82. Amirova, A.; Rodchenko, S.; Filippov, A. Time dependence of the aggregation of star-shaped poly(2-isopropyl-2-oxazolines) in aqueous solutions. J. Polym. Res. 2016, 23, 221. [CrossRef]

83. Lin, P.; Clash, C.; Pearce, E.M.; Kwei, T.K.; Aponte, M.A. Solubility and miscibility of poly(ethyl-oxazoline). J. Polym. Sci. Part B Polym. Phys. 1988, 26, 603-619. [CrossRef]

84. Uyama, H.; Kobayashi, S. A novel thermo-sensitive polymer. Poly(2-iso-propyl-2-oxazoline). Chem. Lett. 1992, 21, 1643-1646. [CrossRef]

85. Diab, C.; Akiyama, Y.; Kataoka, K.; Winnik, F.M. Microcalorimetric study of the temperature-induced phase separation in aqueous solutions of poly(2-isopropyl-2-oxazolines). Macromolecules 2004, 37, 2556-2562. [CrossRef]

86. Bloksma, M.M.; Bakker, D.J.; Weber, C.; Hoogenboom, R.; Schubert, U.S. The effect of Hofmeister salts on the LCST transition of poly(2-oxazoline)s with varying hydrophilicity. Macromol. Rapid Commun. 2010, 31, 724-728. [CrossRef] [PubMed]

87. Schroffenegger, M.; Zirbs, R.; Kurzhals, S.; Reimhult, E. The role of chain molecular weight and Hofmeister series ions in thermal aggregation of poly(2-isopropyl-2-oxazoline) grafted nanoparticles. Polymers 2018, 10, 451. [CrossRef] [PubMed]

88. Magnusson, J.P.; Khan, A.; Pasparakis, G.; Saeed, A.O.; Wang, W.; Alexander, C. Ion-sensitive "Isothermal" responsive polymers prepared in water. J. Am. Chem. Soc. 2008, 130, 10852-10853. [CrossRef] [PubMed]

89. Zhang, Y.; Cremer, P.S. Interactions between macromolecules and ions: The Hofmeister series. Curr. Opin. Chem. Biol. 2006, 10, 658-663. [CrossRef] [PubMed]

90. Zhang, Y.; Furyk, S.; Bergbreiter, D.E.; Cremer, P.S. Specific ion effects on the water solubility of macromolecules: PNIPAM and the Hofmeister series. J. Am. Chem. Soc. 2005, 127, 14505-14510. [CrossRef]

91. Varanaraja, Z.; Kim, J.; Becer, C.R. Poly(2-oxazine)s: A comprehensive overview of the polymer structures, physical properties and applications. Eur. Polym. J. 2021, 147, 110-299. [CrossRef]

92. Yoon, J.A.; Gayathri, C.; Gil, R.R.; Kowalewski, T.; Matyjaszewski, K. Comparison of the thermoresponsive deswelling kinetics of poly(2-(2-methoxyethoxy)ethyl methacrylate) hydrogels prepared by ATRP and FRP. Macromolecules 2010, 43, $4791-4797$. [CrossRef]

93. Park, J.-S.; Akiyama, Y.; Winnik, F.M.; Kataoka, K. Versatile synthesis of end-functionalized thermosensitive poly(2-isopropyl-2oxazolines). Macromolecules 2004, 37, 6786-6792. [CrossRef]

94. Christova, D.; Velichkova, R.; Loos, W.; Goethals, E.J.; Prez, F.D. New thermo-responsive polymer materials based on poly(2ethyl-2-oxazoline) segments. Polymer 2003, 44, 2255-2261. [CrossRef] 